Full-text Available Online at www.ajol.infoand www.bioline.org.br/ja
J. Appl. Sci. Environ. Manage. Sept. 2016

Vol. 20 (3) 599-605

\title{
Distribution of Phthalate Esters in Underground Water from Power Transmission Sites in Warri Metropolis, Delta State, Nigeria
}

\author{
EDJERE, O; ${ }^{* 1}$ ASIBOR, IG; BASSEY, U
}

\author{
Department of Environmental Management and Toxicology, College of Science, Federal University of \\ Petroleum Resources, P.M.B. 1221, Effurun, Delta State, Nigeria. \\ *Corresponding Author, email: asibor.godwin@fupre.edu.ng; tel: +234-8078350554
}

\begin{abstract}
This study investigates the distribution of phthalateacid esters (PAEs) in groundwater from some power stations in Delta State. Groundwater samples were collected from eight power transmission and distribution stations. Concentrations $(\mu \mathrm{g} / \mathrm{L})$ of six phthalate acid esters compounds in the groundwater ranged from 0.000-2.547(DMP), 0.053-0.180(DEP), 0.100-0.443 (DBP), 0.400-0.660(DEHP) and 0.000-0.020 (DnOP), while BBP was not detected in all the locations. Lowest total PAEs concentration was recorded in Edjeba Station $(0.994 \pm 0.040 \mu \mathrm{g} / \mathrm{L})$ while the highest concentration was recorded in Mofo Station $(3.380 \pm 0.012 \mu \mathrm{g} / \mathrm{L})$. Analysis of variance showed significant difference in concentration of DMP $(\mathrm{p}<0.5)$ from the eight transmission stations. DMP, DEP and DBP concentration in groundwater were found to be at level that does not pose immediate threat. Despite this, it would be advisable to continue to monitor the presence of these substances in water. DEHP content was high in most samples from the different stations and this is of serious concern, because it has been proven to be carcinogenic. It is advised that most of the old dilapidated transformers and other electrical equipment containing organic contaminant such polychlorobiphenyl (PCB) which is a major contributor of phthalate acids into water bodiesbe replaced with new ones and concrete bundwall built round the transformers to prevent unwholesome seepages into the environment. There should also be appropriate storage, decontamination and disposal of contaminated units prior to final disposal. Decommissioned transformers and equipment containing PCB should be stored on a concrete pad with curbs sufficient to contain the liquid contents. () JASEM

http://dx.doi.org/10.4314/jasem.v20i3.14
\end{abstract}

Keywords: Transmission stations, Phthalates acid esters, Underground water, GC-MS analysis

Phthalate acid esters (PAEs) are industrially produced non-reactive plasticizers usedin the production of plastics.They are formed when methanol, ethanol or other alcohols react with the carboxyl groups on the benzene ring of phthalicacids. They are diakyl or alkyl esters of 1,2 benzene carboxylic acid (Adeniyi et al., 2008). When added to plastics such as polyvinyl chloride, cellulosic and styrene, their softness and flexibility are improved. Many PAEs andtheir metabolites cause adverse effects on reproduction and development in humans and animals such as testicular and sexual differentiation effects (Ema et al., 1998). Some of these phthalate acid esters are: dimethyl phthalate (DMP), dibutyl phthalate (DBP), di (2-ethylhexyl) phthalate (DEHP), butyl Benzyl phthalate (BBP), Diisodecyl phthalate (DIDP), Diisononyl phthalate (DINP), Di-n-Hexyl-phthalate (DnHP) and Di-noctyl phthalate (DnOP). Others products that contains phthalates include polychlorinated dibenzo-p-dioxins, polychlorinated dibenzofurans,

Organochloropesticides, dichlorodiphenyl, trichloroethylene, nonylphenols, steroid hormones andphthalates. A main route of exposure to phthalates is via water use as these chemicals find their way into the water system through effluent discharges, leaching from waste dumps and through several diffuse sources (WHO, 2003).

Urbanization, intensive agriculture, recreation, and the manufacturing industry are affecting water quality throughout the world. Waste generations by the industries and households have continued to increase. This has led to pollution of inland water bodies and coastal waters and subsequently increased water quality parameters such as heavy metals, nutrients and organic matter, soluble ions, oil and grease, and organic chemicals such as pesticides and poly-nuclear aromatic hydrocarbons (PAHs). Almost all major forms of electricity generations-fossil fuel based, nuclear, large hydro, newer renewable, as well as transmission have raised serious environmental concern (Hester and Harrison, 2006). Highly-refined, mineral insulating oils are used to cool transformers and provide electrical insulation between live 
components. They are typically found in the largest quantities at electrical substations and maintenance shops ((Ifterhar et al., 2013). Sulfur hexafluoride (SF6) may also be used as a gas insulator for electrical switching equipment and in cables, tubular transmission lines, and transformers. SF6 may be used as an alternative to insulating oils. Polychlorinated Biphenyls (PCB) were widely used as a dielectric fluid to provide electrical insulation, although their use has been largely discontinued due to potential harmful effects on human health and the environment.Studies have detected these compounds in wastewater (Olujimi et al., 2012), River water (Liu et al., 2013), seawater and even in sediments (Bastos and Haglund, 2012). They have also been occasionally detected in drinking water (Dévier et al., 2013; Blanchard et al., 2013; Domínguez-Morueco et al. 2014; Irinaet al., 2015) and also bottled water (Levaidara et al, 2007; Dumitrascu, 2012).

In Nigeria, high concentrations of DEHP and DBP (1000 times higher than run-off water samples) in leachates and sediment from a municipal waste deposit site were recorded in Owerri Town (Arukwe et al., 2012).Others are that of Aina et al. (2015) on phthalate esters in Epe and Lagos Lagoons; Adebola and Taiwo (2013) on the sediments and waters of Rivers Ogun and Ibeshe in Southwestern Nigeria; while Maduka et al. (2009) reported some traces of phthalates intap and rain water in Enugu.

Urgent attention is therefore necessary to mitigate water pollution problems in Nigeria through monitoring as well as enforcement of emission standards by industries.Assessment of water is not only for suitability for human consumption but also in relation to its agricultural, industrial, recreational, commercial uses and its ability to sustain aquatic life. Water quality monitoring is therefore a fundamental tool in the management of freshwater resources. To underpin its importance, World Health Organization (WHO), United Nations Environment Programme (UNEP), United Nations Educational, Scientific and Cultural Organization(UNESCO) and World Meteorological Organization (WMO) launched in 1977, a water monitoring programme to collect detailed information on the quality of global ground and surface water. Since Phthalate acids esters in soil can be desorbed and infiltrate into groundwater by rainfall, groundwater may therefore be one of the important reservoirs for PAEs, while PAEs in surface water may directly permeate into groundwater through water flow. Hence this work is aimed at assessing the level of PAEs in groundwater from transmission and distribution power stations.

\section{MATERIALS AND METHODS}

Area of Study: Warri is the economic nerve center of Delta State. It is an oil producing community, second only to the city of Port-Harcourt. It is the most populated town in Delta State. Warri Metropolis comprises Warri, Uvwie and Okpe Local Government Areas with a population of about 800,000 (NBS, 2010). The metropolishave eight distribution substation at Okoloba, Army Barrack, Enerhen, Edjeba, Jeddo, NPA, Mofo, Warri Mains and a transmission station at Alegbo operating a 33,000 volts feeding the various distribution stations which operate at 11,000 volts (Figure 1). Virtually all the distribution substation was built over twenty years ago except Jeddo and Mofo which are less than twenty years old. Used transmission fluids were found spilled around the environment in some of the distribution stations, as there is no bund-wall to curtail their spread. This fluid easily percolates and seep into the underground or are washed into the nearby streams after heavy downpour of rain. There was a general poor housekeeping within most of the facilities visited except the new Mofo Station.

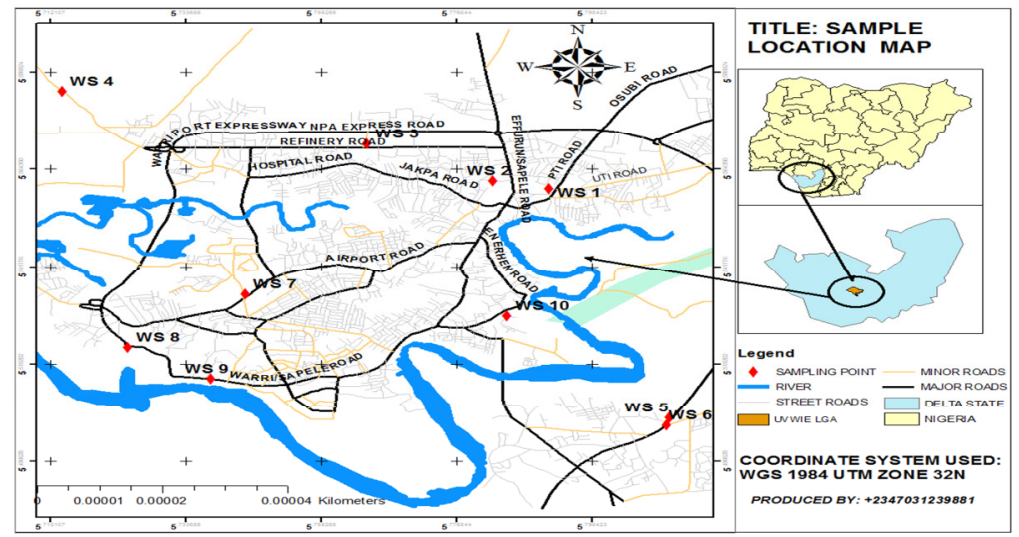

Fig1: Map of sampling location

EDJERE, O; ASIBOR, IG; BASSEY, U 
Sample Collection: Water samples were collected from eight transmission stations (Table 1) in a glass bottle, stored in an ice chest until arrival to the laboratory, where they were kept in fridge.

Table 1: Sample location, codes and grid coordinates

\begin{tabular}{|c|c|c|c|}
\hline $\mathbf{S} / \mathbf{N}$ & Site code & Description & Sampling co-ordinate \\
\hline 1 & WS1 & Alegbo & 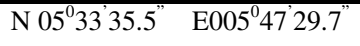 \\
\hline 2 & WS2 & Okoloba & $\mathrm{N} 05^{0} 33^{\prime} 42.0^{\prime \prime} 005^{0} 46^{\prime} 57.5^{\prime \prime}$ \\
\hline 3 & WS3 & Army barrack & $\mathrm{N} 05^{0} 34^{\prime} 13.0^{\prime \prime} \quad \mathrm{E} 005^{\circ} 45^{\prime} 45.2^{\prime \prime}$ \\
\hline 4 & WS4 & Jeddo & $\mathrm{N} 05^{0} 3456.6^{\prime \prime} 005^{0} 42^{\prime} 50.5^{\prime \prime}$ \\
\hline 5 & WS5 & Mofo & $\mathrm{N} 05^{0} 30^{\prime} 24.3^{\prime \prime} 005^{0} 48^{\prime} 38.7^{\prime \prime}$ \\
\hline 6 & WS6 & Edjeba & $\mathrm{N} 05^{0} 32^{\prime} 07.4^{\prime \prime} \quad \mathrm{E} 005^{\circ} 44^{\prime} 35.5^{\prime \prime}$ \\
\hline 7 & WS7 & Warri-Mains & $\mathrm{N} 05^{0} 3056.8^{\prime \prime} \quad \mathrm{E}^{\prime} 05^{\circ} 44^{\prime} 15.8^{\prime \prime}$ \\
\hline 8 & WS8 & Enerhen & $\mathrm{N} 05^{0} 31^{\prime} 49.2^{\prime \prime} \quad \mathrm{E} 005^{\circ} 47^{\prime} 05.7^{\prime \prime}$ \\
\hline
\end{tabular}

Chemicals and materials: Anhydrous sodium sulphate oven heated at $400^{\circ} \mathrm{C}$; cyclohexane distillated in an all glassware;acetone; 1,11Dibromoundecane(ISTD); reagent water; Agilent gas chromatograph 6890N coupled with MS; Sample collection bottles; 11 Erlenmeyer flasks; glass coated metal magnetic mixer; Upward delivery glass separating funnel; $10 \mathrm{ml}$ vials with septum seals (Silicon/PTFE); Balance (3 decimal places); glass beakers; spatulas; forceps; aluminium foil; solvent reservoir bottle; calibrated syringe; ultrasonic bath; bunsen burner; drying oven; muffle furnace; desiccators; measuring cylinders; test tubes; pasteur pipettes; calibrated pipette.

Sample Handling and pre-treatment: Water samples were collected in amber glass containers. Conventional sampling practices were followed. No special sample preservations and storage steps were taken since phthalate are stable at $\mathrm{pH}$ 7.Samples were collected and sealed with a glass stopper followed by a metal clip.The samples were refrigerated at $4{ }^{\circ} \mathrm{C}$ free from light from the time of collection until extraction.

Extraction of Water Sample: A subsample of 1L was weighed into a calibrated Erlenmeyer flask of 1L. To this is added $1 \mathrm{ml}$ Cyclohexane internal Standard solution and then $9 \mathrm{ml}$ Cyclohexane. With the aid of a glass coated magnet the sample was then liquid / liquid intensively extracted for a minimum of an hour. Using an upward delivery glass-separating funnel, the solvent Extract was then isolated in a 10 $\mathrm{ml}$ vial. Sample volume is $1 \mathrm{~L}$ in $10 \mathrm{ml}$ Cyclohexane Extract.

Quality Control: Distilled water used during experimental process was analysed separately for all phthalates acid esters and used as control. Triplicateanalysis was carried out for each phthalates in the water sample.

Analysis of Phthalate in water using GC/MS: The analytes in the extract were separated by means of capillary gas chromatography using temperature programming. The chromatographically separated phthalate esters were detected and measured with Mass Spectrometer. This process is made possible by large volume injection (LVI) technique used to introduce $10 \mu \mathrm{l}$ of the sample solvent extract at a rate of approx. 4.6ul/sec into the injector. The injector is kept at an initial temperature of $78^{\circ} \mathrm{C}$ and rises gradually at the rate of $5^{\circ} \mathrm{C} / \mathrm{sec}$ to $300^{\circ} \mathrm{C}$ so as to enable complete volatilisation of solvent into the analytical column. Oven initial temperature was kept at $70^{\circ} \mathrm{C}$ and on injection rises to $300^{\circ} \mathrm{C}$ at a rate of $20^{\circ} \mathrm{C} / \mathrm{min}$. Injector's temperature is brought back quickly to normal by the use of a liquid Nitrogen cryo cooling unit.The new method for analysis of Phthalate in water samples using GC/MS was validated according to Skoog et al. (1998), Edjere (2006) and Institute Bachema AG Quality Management Guidelines as certified by ISO 17025 (Institute Bachema, 2004; 2006).

\section{RESULT AND DISCUSSION}

Total phthalate acid esters for each of the locations are shown in Table 2. Highest total phthalates concentration was recorded in Mofo Station $(3.38 \pm 0.0116 \mu \mathrm{g} / \mathrm{L})$ followed by Alegbo and Army Barracks Stations with a concentration of $2.623 \mu \mathrm{g} / \mathrm{L}$ and $2.15 \mu \mathrm{g} / \mathrm{L}$ respectively while the lowest total phthalates concentrations was recorded in Edjeba Station followed by Warri Main and Enerhen Stations with concentrations of $0.993 \mu \mathrm{g} / \mathrm{L}, 1.143 \mu \mathrm{g} / \mathrm{L}$ and $1.213 \mu \mathrm{g} / \mathrm{L}$. 
The pattern of phthalate acid concentration for each of the stations are DEHP $>$ DMP $>$ DBP $>$ DEP $>$ DnOP $>$ BBP $($ Edjeba $)$, DEHP $>$ DBP $>$ DMP $>$ DEP $>$ DnOP $>$ BBP (Okoloba), DMP $>$ DEHP $>$ DBP $>$ DEP $>$ DnOP $>$ BBP $(\mathrm{Ar}$ my

\section{$\mathrm{DMP}>\mathrm{DEHP}>\mathrm{DBP}>\mathrm{DEP}>\mathrm{DnOP}>\mathrm{BBP}$}

(Mofo), DMP $>$ DEHP $>$ DEP $>$ DBP $>$ DnOP $>$ BBP $($ Jedd o), $\quad \mathrm{DEHP}>\mathrm{DBP}>\mathrm{DEP}>\mathrm{DMP}>\mathrm{DnOP}>\mathrm{BBP} \quad($ Warri Mains),

$\mathrm{DMP}>\mathrm{DBP}>\mathrm{DEHP}>\mathrm{DEP}>\mathrm{DnOP}>\mathrm{BBP}($ Alegbo $)$ and $\mathrm{DEHP}>\mathrm{DBP}>\mathrm{DEP}>\mathrm{DMP}>\mathrm{DnOP}>\mathrm{BBP}($ Enerhen $)$ as shown in Figure 2.This shows that DEHP was generally more prevalent and has highest concentrations in most of the Station. It was followed by DMP and DBP. The least occurring phthalate was BBP, which was not detected in all the locations. It was closely followed by DnOP and DEP. Concentrationn of DEHP is pronounced in $50 \%$ of the sampling region, this is not surprising as DEHP is the most used phthalates. Jianlong et al.(2000) and Chang et al. (2004) pointed out that phthalates with shorter ester chains, like DMP, DEP, DBP, DPP and BBP can be readily biodegraded and mineralized, whereas phthalates with longer ester chains, such asDEHP, are less susceptible to biodegradation. This may account for the low concentrations of BBP and
DEP in the stations and high concentrations of DEHP. The biodegradability of the different phthalates is likelydue to the steric effect of phthalates side ester chains, whichhinders the hydrolytic enzymes from binding to thephthalates and thereby inhibits their hydrolysis (Xia et al., 2004).Concentration of DEHPwas lower than that reported by Wen-Long et al., (2015)in source water with median value of $1.3 \mu \mathrm{g} / \mathrm{Lentering}$ the water treatment plant and $0.064 \mu \mathrm{g} / \mathrm{L}$ after various treatment processes was carried out. Irina (2015) reportedDEHP concentrations were below detection limits $(<0.015 \mu \mathrm{g} / \mathrm{L})$ for all the samples analyzed inside drinking water treatment plant in Cluj, Romania.

DMP was observed to be more in Mofo Station $(2.5467 \mu \mathrm{g} / \mathrm{L})$ and less in Warri Mains and Enerhen $(0.000 \mu \mathrm{g} / \mathrm{L})$. Hence possibility of DMP degradation is not ruled out. Concentrations ranged from 0.0000$2.5467 \mu \mathrm{g} / \mathrm{L}$ which is the highest phthalate acid ester concentration obtained. Water solubility of the alkyl phthalate ester generally varies inversely with the length of the alkyl side chain. Dimethyl phthalate (DMP) was the most hydrophilic and water soluble of the esters. The $\mathrm{C}_{10}, \mathrm{C}_{11}$, and $\mathrm{C}_{13}$ esters are the most hydrophobic and least water soluble.

Table 2: Concentration $(\mu \mathrm{g} / \mathrm{L})$ of phthalate esters from studied locations

\begin{tabular}{lllllllll}
\hline S/N & Sites & DMP & DEP & BBP & DBP & DEHP & DnOP & Total \\
\hline $\mathbf{1}$ & Edjeba & $0.367 \pm 0.0058^{\mathrm{a}}$ & $0.0533 \pm 0.023^{\mathrm{a}}$ & N.D & $0.120 \pm 0.000^{\mathrm{b}}$ & $0.4533 \pm 0.0115^{\mathrm{bc}}$ & N.D & $0.9936 \pm 0.0403$ \\
$\mathbf{2}$ & Okoloba & $0.260 \pm 0.0000^{\mathrm{b}}$ & $0.0933 \pm 0.05774^{\mathrm{ab}}$ & N.D & $0.400 \pm 0.000^{\mathrm{e}}$ & $0.6267 \pm 0.02309^{\mathrm{e}}$ & N.D & $1.3800 \pm 0.08033$ \\
$\mathbf{3}$ & Army barrack & $1.267 \pm 0.015^{\mathrm{c}}$ & $0.0533 \pm 0.0577^{\mathrm{a}}$ & N.D & $0.3700 \pm 0.0173^{\mathrm{d}}$ & $0.4600 \pm 0.0000^{\mathrm{c}}$ & 0.0000 & $2.1503 \pm 0.0865$ \\
$\mathbf{4}$ & Mofo & $2.5467 \pm 0.0000^{\mathrm{d}}$ & $0.1400 \pm 0.0000^{\mathrm{bc}}$ & N.D & $0.2533 \pm 0.01155^{\mathrm{c}}$ & $0.440 \pm 0.0000^{\mathrm{b}}$ & 0.0000 & $3.38 \pm 0.01155$ \\
$\mathbf{5}$ & Jeddo & $1.0200 \pm 0.0000^{\mathrm{e}}$ & $0.1133 \pm 0.0115^{\mathrm{b}}$ & N.D & $0.1000 \pm 0.000^{\mathrm{a}}$ & $0.4867 \pm 0.0462^{\mathrm{d}}$ & N.D & $1.72 \pm 0.0577$ \\
$\mathbf{6}$ & Warri mains & $0.0000 \pm 0.0000^{\mathrm{f}}$ & $0.1233 \pm 0.0058^{\mathrm{bc}}$ & N.D & $0.3600 \pm 0.0000^{\mathrm{d}}$ & $0.6400 \pm 0.00000^{\mathrm{e}}$ & $0.02 \pm 0.00$ & $1.1433 \pm 0.0058$ \\
$\mathbf{7}$ & Alegbo & $1.5800 \pm 0.0000^{\mathrm{g}}$ & $0.1800 \pm 0.000^{\mathrm{c}}$ & N.D & $0.4433 \pm 0.0058^{\mathrm{f}}$ & $0.4000 \pm 0.00000^{\mathrm{a}}$ & $0.02 \pm 0.00$ & $2.6233 \pm 0.0058$ \\
$\mathbf{8}$ & Enerhen & $0.00000 \pm 0.0000^{\mathrm{f}}$ & $0.1400 \pm 0.0000^{\mathrm{bc}}$ & N.D & $0.4133 \pm 0.01155^{\mathrm{e}}$ & $0.6600 \pm 0.00000^{\mathrm{f}}$ & N.D & $1.2133 \pm 0.01155$ \\
Total & & $7.0407 \pm 0.0058$ & $0.8965 \pm 0.1557$ & N.D & $2.4599 \pm 0.1502$ & $4.1667 \pm 0.0808$ & $0.04 \pm 0.00$ & $14.6038 \pm 0.3000$ \\
Min & & 0.000 & 0.0533 & N.D & 0.1000 & 0.4000 & 0.0000 & 0.9936 \\
& & & & & & & & \\
Max & 2.5467 & 0.1800 & N.D & 0.4433 & 0.6600 & & & \\
\end{tabular}

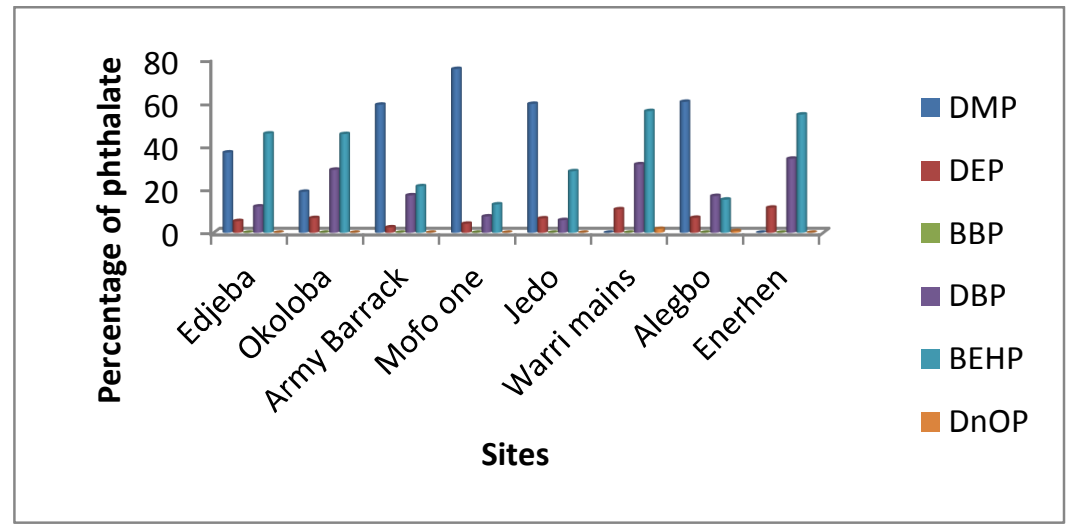

Fig 2: Percentages contribution of each Phthalates in the sampled water 
The sorption of phthalate esters to soil, sediment, or suspended solids is partially governed by their relative hydrophobicity (Staples et al., 1997). Although values obtained are less thanthe maximum contamination level $(5.0 \mathrm{mg} / \mathrm{l})$. This is higher than that reported by Domínguez-Moruecoet al, (2014) for Phthalate levels in drinking water samples from the main supply areas for Madrid in contrast to river water samples in drinking water samples $0.0011 \mu \mathrm{g} / \mathrm{L}$

DBPand DEP concentration tends to be less in most station ranging from $0.0533-0.1400 \mu \mathrm{g} / \mathrm{L}$ forDBP and $0.120-0.4433 \mu \mathrm{g} / \mathrm{Lf}$ for DEP. Highest concentration of these phthalate esters was obtained at Alegbo transmission station. Edjeba and Jeddo distribution station was the least contributor to DEP and DBP values. Result obtained was in agreement with that reported by Kanchanamayoonet al., (2012) where concentration of $0.11 \mathrm{mg} / \mathrm{l} \mathrm{DEP}$ was found in drinking water sample and DBP not detected. Hadjmohammadi et al.(2010) also reported that DEP and DBP was not found in tap water sample in Babolsar, Mazandaran Province in the north of Iran.Although result showed that values of these pollutants are insignificant compared to allowable standard, bioaccumulation might pose health challenge if not checked.

In Figure 3, total phthalate acid ester concentration ranged between $0.9936 \mu \mathrm{g} / \mathrm{L} \quad( \pm 0.0403 \mu \mathrm{g} / \mathrm{L})$ to $3.38 \mu \mathrm{g} / \mathrm{L}( \pm 0.01155 \mu \mathrm{g} / \mathrm{L})$.Edjeba and Warri Mains Station have lowest concentration while Mofo and Alegbo Stations have the highest concentration. Warri Mains distribution station was the first among all the station, which was built about 32 years ago. Microbial activities would have led to degradation of lower molecular weight phthalate. From Table 2, concentration of PAEs at Warri station is of the pattern $\mathrm{DMB}<\mathrm{DBP}<\mathrm{DEP}<\mathrm{DEHP}$ with observed concentration of DEHP $(0.6400 \mu \mathrm{g} / \mathrm{L})$ at this station is on the high side compared to DMP $(0.0000 \mu \mathrm{g} / \mathrm{L})$.

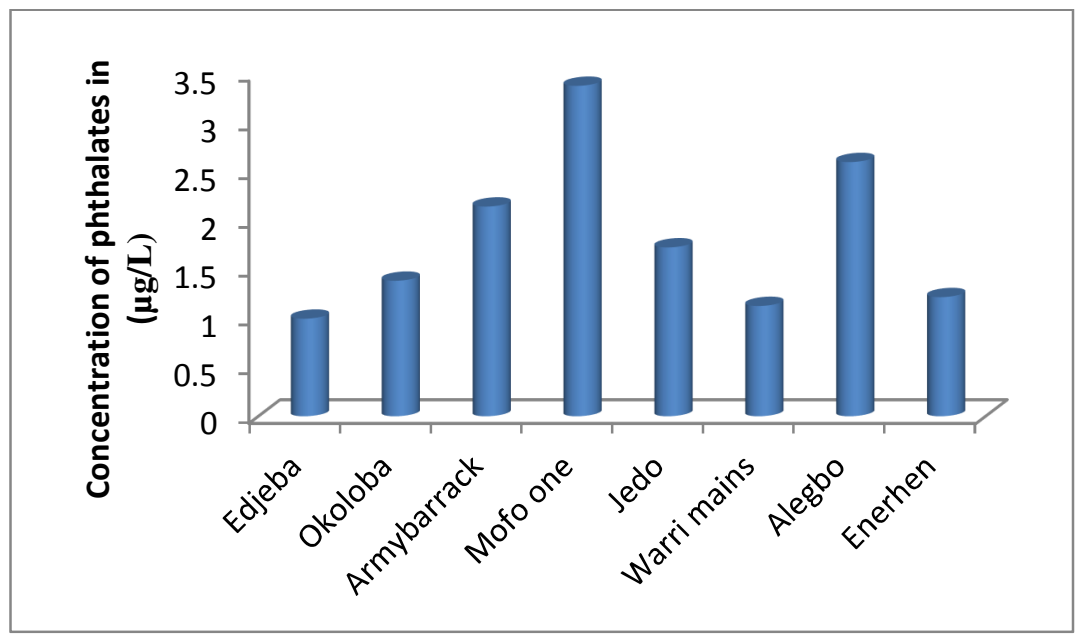

Fig 3: Total phthalate acid concentration from sampling region.

DMP, DEP and DBP concentration in the groundwater were found to be at level that does not pose immediate threat. DEHPcontent was high in most samples from the different stations and this is of serious concern, because the compound has been proven to be carcinogenic (WHO, 2003).DEHP also known asdi-(2-ethylhexyl) phthalate is considered to be a priority hazardous substance in the latest proposed directive (Directive 2013/39/UE) from the European Parliament and theCouncil (2013) concerning priority substances in the field of water policy, so it is abnormal that it was found in samples. DEHP in water poses serious risks of cancer in humans, especially when using the water for dermal absorption (bathing) and drinking purposes.
It is in the opinion of the authors that existing transformers and other electrical equipment containing organic contaminant such polychlorobiphenyl (PCB) which is a major contributor of phthalate acids in the premises of power transmission and distribution should be appropriately stored in their warehouse with concrete bundwalls erected around them to prevent leakages into the open environment. Old and decommissioned units should be properly decontamination.Prior to final disposal, retired transformers and equipment containing PCB should be stored on a concrete pad with curbs sufficient to contain the liquid contents. Most important, Nigerian government should set up indigenous own standard for phthalate acid esters in consumed products. 
Acknowledgements: The authors would like to appreciate and thank all the Staff and management team at Bachema Analytical Laboratories Rutistrasse 22, Schlieren-Zurich, Switzerland for creating an enabling environment for the analysis of the samples presented in this publication.

\section{REFERENCES}

Adebola, A;Taiwo, $\mathrm{O}(2013)$. Determination of Nonylphenol,Octylphenol and Bisphenol-A in Water and Sediments of Two Major Rivers in Lagos,Nigeria.Journal of Environmental Protection.4: 38-45.

Adeniyi, A;Dayomi, M;Siebe, P;Okedeyi, $\mathrm{O}(2008)$.An assessment of the levels of phthalate esters and metals in the Muledane open dump, Thohoyandou, Limpopo Province, South Africa. Chemistry Central Journal.2:9-18

Aina, O;Adeogun, A; Oju, R; Ibor,A;Emmanuel, D; Omogbemi, A; Azubuike, V; Chukwuka, RA; Adegbola, AGA; Adewuyi, A;Arukwe, A (2015). Environmental occurrenceand biota concentration of phthalate esters in Epe and Lagos Lagoons, Nigeria.MarineEnvironmental Research.108:24-32.

Arukwe, A;Eggen, T;Moder, M (2012). Solid waste deposits as a significant source of contaminants of emerging concern to the aquatic and terrestrial environments in a developing country case study from Owerri, Nigeria. Sci. Total Environ.438: 94-102.

Bastos, PM;Haglund, P (2012). The use of comprehensive two-dimensional gas chromatography and structure-activity modeling for screening and preliminary risk assessment ofcontaminants in soil, sediment, and surface water.Journal of Soils Sediments. 12(7):1079-88

Blanchard, M; Teil, MJ;Dargnat, C;Alliot, F; Chevreuil, M(2013).Assessment of adult human exposure to phthalate esters in the urban centre of Paris (France).Bulletin of Environmental Contamination and Toxicology.90(1):91-96.

Chang, BV; Yang, CM; Cheng, CH; Yuan, SY(2004). Biodegradation of phthalate esters by twobacteria strains.Chemosphere.55:533-538.

Dévier, MH; Le Menach, K;Viglino, L; Di Gioia, L;Lachassagne, P; Budzinski, H (2013). Ultra trace analysis of hormones, pharmaceutical substances, alkylphenols and phthalates intwo French natural mineral waters.Science of the Total Environment.443:621-632.

Domínguez-Morueco, N. S., González-Alonso, S. and Valcárcel, Y. (2014).Phthalate occurrence in rivers and tap water from central Spain.Science of the Total Environment.20: 139-146.

Dumitrascu, I (2012). Determination of phthalates from bottled water by GC-MS. Air and Water Conference. 10:337-343.

Edjere, O (2006). Trace determination of phthalates in groundwater samples by GC-MS using specific sample concentration techniques. M.Sc. Thesis, Dept. of Environmental Chemistry, Robert Gordon University, Aberdeen, Scotland.

Ema, M;Miyawaki, E; Kawashima, K (1998).Further evaluation of developmental toxicity of di- $n$ butyl phthalate following administration during late pregnancy in rats.ToxicologyLetters.98: 8793.

Hadjmohammadi, MR; Fatemi, MH;Taneh, T (2010). Conservative Extraction ofPhthalates from Water and Their Determination by High Performance LiquidChromatography.Journal of the Iranian Chemical Society.4: 37-44

Hester, RE; Harrison, RM (2006). Environmental Impact of Power Generation.11, X001 X002 DOI:10.1039/9781847550774-FX001.

Iftekhar, ZA;Tausif, A;Shidujaman, M;Mayen, H (2013). Consideration of EnvironmentalEffect of Power Generation: Bangladesh Perspective. Energy and Power Engineering.5:1521-1525

Institute Bachema AG (2004). Analytical laboratories Handbook for Quality Management Guidelines (Institute Bachema QRL-Verzeichnis, version 04) ISO 17025 Certified 2004.

Institute Bachema AG (2006). Analytical laboratories Safety Manual materials and chemicals. LIMSOPHY-Laboratory Information and Management System. ISO-17025 Certified 2006.

Irina,Dumitraşcu, Anca Elena Gurzău, EugenStelianGurzău. (2015). A pilot study ondetermination of phthalates from drinking water system supply of Cluj-Napoca by 
solidphase extraction and GC-MS analysis.Wulfenia Journal22 (4): 1348-1257.

Jianlong, W;Lujun, C;Hanchang, S; Yi, Q (2000).Microbial degradation of phthalic acid esters underanaerobic digestion of sludge.Chemosphere. 41:1245-1248.

Kanchanamayoon, W; Prapatpong, $\mathrm{P}$;Chumwangwapee, S;Chaithongrat, $\mathrm{S}$ (2012).Analysis of Phthalate Esters Contamination in Drinking Water Samples.African Journal of Biotechnology.11 (96): 16263-16269,

Leivadara, SV; Nikolaou, AD;Lekkas, TD (2007). Determination of organic compounds in bottled waters, Food Chemistry. 108:277-286

Liu, P;Tian, T;Barreto, J; Chou, J(2013). Assessment and analysis of phthalate esters, in Lake Pontchartrain by SPME combining with GCMS. Environment Technology.34(4):37-41.

Maduka, IC;Ezeonu, FC;Neboh, EE;Shu, EN (2009). Preponderance of Bisphenol-A inHarvested Rain Water in Enugu Municipality, South East, Nigeria.Research Journal ofEnvironmental and Earth Sciences.2(1): 36-38

NBS (2010).National Bureau of Statistics, Annual Abstract of Statistics, Federal Republic of Nigeria.
Olujimi, OO;Fatoki, OS;Odendaal, JP;Daso, $\operatorname{AP}(2012)$. Chemical monitoring and temporal variation in levels of endocrine disrupting chemicals (priority phenols and phthalateesters) from selected wastewater treatment plant and freshwater systems in Republic ofSouth Africa.Microchemical Journal. 101:11-23.

Skoog, DA; Holler, FA;Nieman, TA (1998).Principles of Instrumental Analysis. $5^{\text {th }} \mathrm{ed}$. Thompson Learning Academic Resource Center, United States.

Staples, CA; Peterson, DR;Urbanerton, TF; Adams, WJ(1997). The environmental fate of phthalate esters: a literature review. Chemosphere. 35: 234-244

Wen-Long, W; Qian-Yuan W; Chao, W; Tao, H; Hong-Ying, $H$ (2015). Healthrisk assessment of phthalate esters (PAEs) in drinking water sources of China.Environmental Science Pollution Research. DOI 10.1007/s11356-014-3615-z

WHO (2003).World Health Organization Guidelinesfor Drinking-WaterQuality.Geneva. (WHO/SDE/WSH/03.04/68).

Xia, F;Zheng, PZQ; Feng, X (2004).Relationship between quantitative structure and biodegradability for phthalic acid ester compounds.Life science.30:141-146. 